University of Nebraska - Lincoln

DigitalCommons@University of Nebraska - Lincoln

Agronomy \& Horticulture -- Faculty Publications

Agronomy and Horticulture Department

1989

\title{
Teaching Weed Identification at Twenty U.S. Universities
}

John L. Lindquist

University of Nebraska-Lincoln, jlindquist1@unl.edu

Peter Fay

University of Nebraska-Lincoln

James Nelson

Montana State University

Follow this and additional works at: https://digitalcommons.unl.edu/agronomyfacpub

Part of the Plant Sciences Commons

Lindquist, John L.; Fay, Peter; and Nelson, James, "Teaching Weed Identification at Twenty U.S. Universities" (1989). Agronomy \& Horticulture -- Faculty Publications. 625.

https://digitalcommons.unl.edu/agronomyfacpub/625

This Article is brought to you for free and open access by the Agronomy and Horticulture Department at DigitalCommons@University of Nebraska - Lincoln. It has been accepted for inclusion in Agronomy \& Horticulture -Faculty Publications by an authorized administrator of DigitalCommons@University of Nebraska - Lincoln. 


\title{
Teaching Weed Identification at Twenty U.S. Universities ${ }^{1}$
}

\author{
JOHN L. LINDQUIST, PETER K. FAY, and JAMES E. NELSON ${ }^{2}$
}

\begin{abstract}
The methods used to teach weed identification at 20 U.S. universities were obtained for comparison through a telephone survey in December, 1986, and January, 1987. Weed identification is taught as a portion $(30 \%)$ of the laboratory section in introductory weed science courses. Only five have a separate weed identification course. Field trips frequently are used to teach weed identification. Students must learn from 50 to 125 weed species with some seedling identification. Pressed plant collections of approximately 50 weed species normally are required. Most instructors strongly suggest using live plants and repetition for long-term learning.
\end{abstract}

\section{INTRODUCTION}

Weed identification is important to weed science since identifying troublesome weed species is the foundation of sound weed management $(5,6)$. Weed seedling identification is important to timely implementation of appropriate weed control practices (9). When representatives from the herbicide industry were asked to develop a list of priorities for knowledge concerning weed biology (8), weed identification was rated 3.6 on a scale of 1 (low) to 4 (high).

Weed identification is a neglected skill among producers and agribusiness personnel possibly because teaching weed identification is not emphasized at the university level. A telephone survey of 20 U.S. universities was conducted to determine the emphasis on weed identification and teaching methods.

\section{MATERIALS AND METHODS}

A letter and a stamped, return-addressed postcard were sent to weed scientists at 35 U.S. universities. Recipients were asked to forward the letter to the weed identification instructor who was asked to return the postcard if he/she would participate in a 20-minute telephone survey. Twenty responded; and the survey was conducted during December, 1986, and January, 1987. Each participant answered a series of questions about teaching methods used for weed identification.

\section{RESULTS AND DISCUSSION}

Weed identification is taught as part of the introductory weed science course at most universities. Of

\footnotetext{
${ }^{1}$ Received for publication Dec. 9, 1987, and in revised form Oct. 12, 1988. Contribution No. J-2160 from Mont. Agric. Exp. Stn.

${ }^{2}$ Student, Assoc. Prof., and Asst. Prof., respectively. Plant Soil Sci. Dep., Mont. State Univ., Bozeman, MT 59717.
}

the 20 instructors surveyed, only five taught a separate weed identification course. In many cases, weed identification used approximately $30 \%$ of the laboratory portion of the "Principles of Weed Science" course. The majority of students taking the weed science/weed identification course were majoring in either agronomy, agricultural sciences, horticulture, or animal and range science.

All but one of the instructors used field trips to teach weed identification (Figure 1). An average of three trips were taken per quarter or semester. The actual number of trips fluctuated from year to year because of weather, available time, and monetary constraints. Most field trips were taken near campus because of time limitations. Some instructors took students to university research farms to observe weeds growing under natural field conditions. The instructors at the Universities of Arkansas, Florida, and Missouri establish weed nurseries for class use. Students at the Universities of Minnesota and Wyoming visit an herbarium to observe collection and storage procedures used for professional reference specimens.

The number of weed species students were required to learn varied from 50 to 125 (Figure 2). In general, students were required to learn both common and Latin names, plant family, and life duration. At several universities, the instructor requires students to become familiar with the characteristics of plant families. On exams, students must use their knowledge of family characteristics and a taxonomic key to identify specimens which belong to those families. Instructors using this approach urged adoption because the method fosters long-term learning rather than short-term memorization of individual plant species.

Identification of some weed seedlings and seeds was required by 17 and 12 instructors, respectively. Weed seedlings are easy to grow in a short time and
Weed Technology. 1989. Volume 3:186-188 


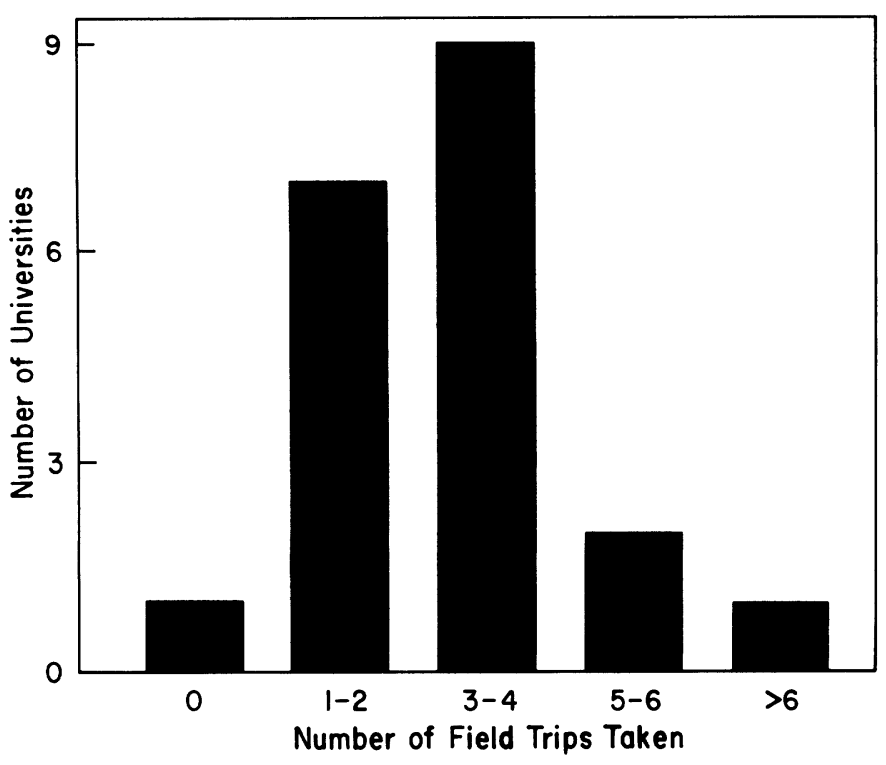

Figure 1. The number of field trips taken per course for weed identification.

require little greenhouse space. One instructor plans to film a number of weed species on a weekly basis during the seedling stage so each growth stage can be observed. The video tapes will be available to students as an audio-tutorial exercise. Several instructors make greenhouse-grown plants available to students for observation.

At one university, students are required to obtain a 5 -kg soil sample from a cultivated field near their homes. The soil is screened, is mixed with $50 \%$ sand to improve drainage, and is placed in a flat in the greenhouse. Weed seedlings which emerge must be identified during the quarter. Some instructors used a weed seedling key (4), although they often complained that these were incomplete. Having students develop their own seedling key based on actual ob-

Table 1. The number of universities which required pressed weed specimen collections.

\begin{tabular}{cc}
\hline Universities & Weed species collected \\
\hline (no.) & $($ no. $)$ \\
4 & 0 \\
4 & 25 \\
11 & $26-50$ \\
1 & $51-75$ \\
\hline
\end{tabular}

served characteristics is an effective teaching technique.

Most instructors required students to make pressed weed collections (Table 1). While the number of collected species varied from 25 to 75 , most instructors required approximately 50 species. Generally, the collections were labeled using standard herbarium specimen-labeling techniques. Some collections included seeds and seedlings in addition to mature specimens. Dr. Beverly Durgan at the University of Minnesota required floral formulas and floral diagrams. Using pressed weed collections enables students to identify and to collect field-grown plant samples.

Students at one university took a comprehensive exam on the first and last days of class and six months after completing the course. The "pre-test" and final exam established the level of knowledge at entry and completion of the course. The optional exam six months later was taken without preparation to measure information retention. The average scores on the final exam and post exam in 1986 were 89 and $80 \%$, indicating significant information retention.

At Montana State University, we use a "weed trail" through a weed garden to stress repetition. The trail is a roto-tilled path through a weedy cultivated area where a seedbed is prepared on three different dates during the growing season to encourage weed emerg-

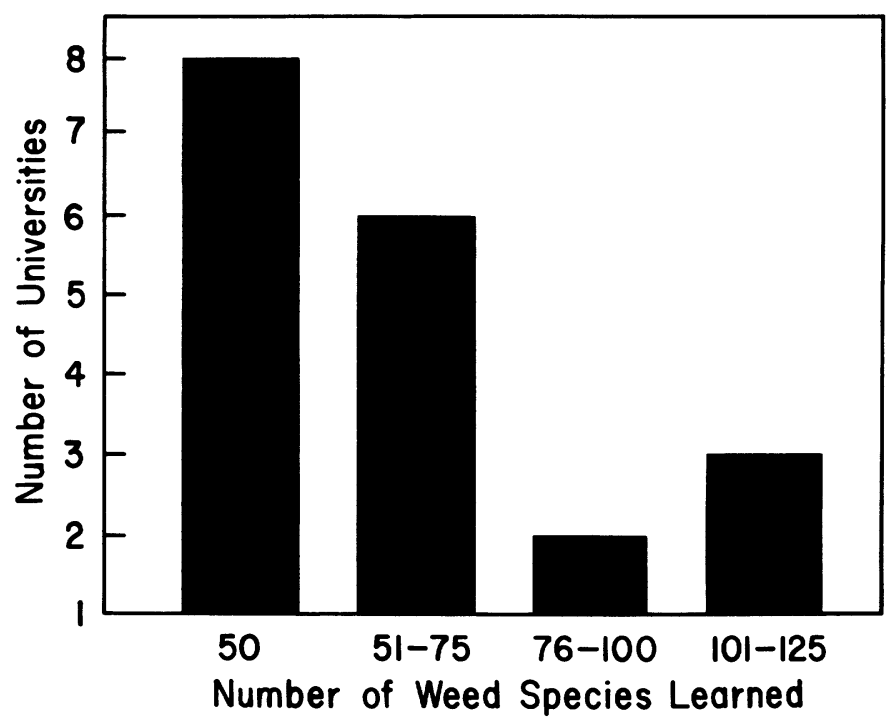

Figure 2. The number of weed species students at 20 universities were required to learn. 
Table 2. Instructors' evaluation of their overall weed identification teaching effort using a rating system of 1 through 10 where $1=$ unsatisfactory and $10=$ excellent.

\begin{tabular}{ll}
\hline Rating & Number of instructors \\
\hline 4 & 1 \\
5 & 2 \\
6 & 1 \\
7 & 9 \\
8 & 3 \\
9 & 4 \\
$\bar{x}$ & 7.2 \\
\hline
\end{tabular}

ence. Ten new weed species are presented each class period twice a week for a total of 60 weeds. Each species is assigned a number and is flagged permanently three times along the trail so students can observe three specimens of each species in a natural setting. A comprehensive quiz in the field at the beginning of every class period covers the common and Latin name of all species previously assigned. This frequent and consistent testing policy motivates students to visit the weed garden. After the quiz, specimens of the species assigned that day are collected and are pressed in plant presses which are issued to each student during the first class meeting.

One reason weed identification is not taught uniformly at all universities is the lack of an appropriate text book. Seven universities in only one region, the upper Midwest, reported significant use of one text "Weeds of the North Central States" (1). Several respondents from the southern states reported using the Weed Identification Guide (2) published by the Southern Weed Science Society.
While the weed spectrum varies from state to state, an effective universal weed identification text should cover basic plant taxonomy, including the development of plant keys, floral diagrams and formulas, plant families, and plant morphology terminology. The required weed species would be left to the individual instructor. Many instructors rely extensively on the use of live plants grown in the field, weed nurseries, and greenhouse. Many stated that repetition both in terms of repeated exposure and testing of plant identification was necessary to achieve longterm learning.

Weed identification should be taught more intensively and uniformly to undergraduates majoring in agriculture. Most instructors were not completely satisfied with the weed identification portion of their course (Table 2). Various methods should be used to teach weed identification since students respond positively to varied teaching techniques $(3,7)$.

\section{LITERATURE CITED}

1. Anonymous. 1981. Weeds of the North Central States. North Cent. Region. Res. Pub. No. 281. Univ. Ill., Urbana, IL. Bull. 772.

2. Anonymous. 1988. Weed Identification Guide. Vol. 1-3. South Weed Sci. Soc., 309 W. Clark St., Champaign, IL.

3. Brown, L. G., and K. J. Karnok. 1985. Supplementing crop and weed identification exercises with prepared slide sets. J. Agron. Ed. $14: 41-43$.

4. Chase, R. L. 1984. A simplified key to identification of weedy plant families. Proc. West. Soc. Weed Sci. 36:193-195.

5. Cramer, G. L., and O. C. Burnside. 1980. Weeds - identification aids in control. Farm, Ranch, Home Q., Nebr. 27:12-13.

6. Khodayari, K., and L. R. Oliver. 1983. A vegetative seedling key for common monocots. Arkansas Farm Res. 32(4):9.

7. Milford, M. H. 1984. Ideas for success in the classroom. J. Agron. Ed. $13: 69-71$.

8. Parka, S. J. 1976. The identification and utilization of weed biology information. Weed Sci. 24:282-287.

$\rightarrow$ Stucky, J. M. 1984. Comparison of two methods of identifying weed seedlings. Weed Sci. 32:598-602. 